\title{
室内空気中のガス状および粒子状ギ酸濃度の測定方法の開発
}

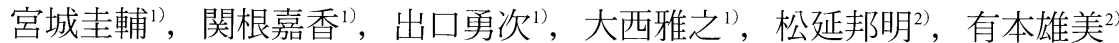

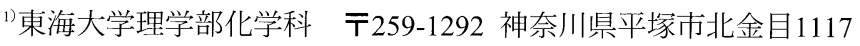

2)株式会社ガステック（２52-1195 神奈川県綾瀬市深谷中8-8-6

\section{Development of method for measuring concentrations of gaseous and particulate formic acid in indoor air}

\author{
Keisuke Miyashiro $^{1)}$, Yoshika Sekine ${ }^{1)}$, Yuji Deguchi ${ }^{1)}$, Masayuki Onishi ${ }^{1)}$, \\ Kunitoshi Matsunobu ${ }^{2)}$ and Takemi Arimoto ${ }^{2)}$ \\ ${ }^{10}$ Department of Chemistry, School of Science, Tokai University, 1117 Kitakaname, Hiratsuka, Kanagawa, 259-1292 Japan \\ ${ }^{2)}$ Gastec Corporation, 8-8-6 Fukayanaka, Ayase, Kanagawa, 252-1195 Japan \\ 要 旨 \\ 室内空気中のギ酸は，ホルムアルデヒドなどの有機化合物とオキシダントとの反応により生成する二次污 \\ 染物質であり，皮膚や粘膜に対する刺激性を有することからシックハウス症候群に関与する可能性が指摘さ \\ れている。一方, 空気中のギ酸は塩基性物質と反応するとギ酸塩となり, 蒸気圧が低くなるためエアロゾル \\ 粒子として存在する可能性がある。そこで本研究では, 室内空気中のギ酸濃度をガス状㧍よび粒子状に分け \\ て測定するため，ミニチュア拡散スクラバーノインピンジャー捕集 - イオンクロマトグラフ法を開発した。

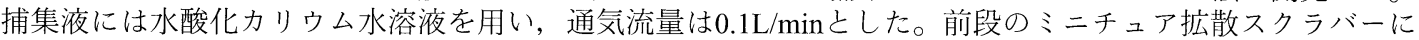 \\ よるガス状ギ酸の捕集効率は $94 \%$ ，捕集したギ酸の再揮発やミニチュア拡散スクラバー内への粒子沈着の影 \\ 響は見られなかった。また本法によるギ酸捕集量の総量は，従来のインピンジャ一法と一致した。本法を用 \\ いて居住住宅において実態調査を行ったところ, 室内空気中のギ酸は, はじめはガス状物質として生成し, \\ 徐々に粒子化していくことがわかった。ギ酸の粒子化機構として，空気中の塩基性物質との反応に伴うギ酸 \\ 塩の生成，および空気中エアロゾル粒子への吸着などが考えられるが，同一住宅でも測定日によっては粒子 \\ 化が起こらない場合ああり，粒子化のメカニズムは不明な点が多い。
}

\begin{abstract}
In modern living environments, humans are exposed to numerous types of pollutants in indoor air. However, secondary emission products generated through chemical reactions have not been fully concerned in relation to so-called Sick House Syndrome. In this study, we focused on formic acid suspected to have impact on human health such as chemical sensitivity due to its low irritant level. Gas to particle conversion is a possible way of decay of gaseous formic acid in indoor air due to lower vapor pressure of formate. Then, authors have developed a sampling apparatus, by serially connecting miniature diffusion scrubber, impinger and air pump, for the determination of gas-particle distribution of formic acid in indoor air. Ion chromatography was employed for the analysis of formate ion trapped in the aqueous potassium hydroxide in each sampling device. The collection efficiency of the gaseous formic acid by the first stage scrubber was $94 \%$ without back-diffusion of trapped formic acid and sink of particles in the scrubber. Collection amount of formate species by this system was equivalent to that by a previous impinger method. Field measurements were conducted at occupied houses. The results showed the formic acid was firstly generated as gaseous form and gradually changed to particulate form with time in indoor air of the houses. However, the conversion mechanism was still unknown, because the gas-particle ratio was not consistent by the day even in the same house.
\end{abstract}

Key words: ギ酸 (formic acid)，室内化学反応 (indoor air chemistry)，ミニチュア拡散スクラ バー(miniature diffusion scrubber)，ガス-粒子分布 (gas-particle distribution)，イ オンクロマトグラフィー(ion chromatography)

\section{1. 緒言}

我が国ではシックハウス問題に対する行政的な対 応として, 室内化学物質濃度指針值の設定(厚生労 働省), 住宅の品質確保の促進に関する法律の整備 (国土交通省)，建築基準法の改正(国土交通省)など が進められている。しかしながら, 室内の化学反応
によって二次的に生成する有害物質に対しては十分 に配慮されていない。またシックハウス症候群の原 因物質については完全に解明されておらず"，室内 化学反応による有害生成物がこれに関与している可 能性も考えられる。

ホルムアルデヒド (HCHO) は主要な室内空気污染 物質の一つであるが，容易に酸化されギ酸 $(\mathrm{HCOOH})$ に変化する。ギ酸は皮膚や粘膜に強い刺 
激性を有しており，ヒトへの影響として3〜 $7 \mathrm{mg} / \mathrm{m}^{3}$ のギ酸曝露により鼻の障害, せき, 鼻炎, のどの不 快感, 気管支炎㧍よび呼吸困難がみられると報告さ れている2)。三好ら゙はホルムアルデヒドから生成す るギ酸がアレルギー様作用を引き起こすとし，ギ酸 が化学物質過敏症の原因物質の一つである可能性を 示唆している。

Wolkoff et $a l^{4 \cdot 6)}$ は天然木材から放散され本来は無 害である $\alpha$-ピネンがオゾンなどのオキシダント (酸化性物質) と反応するとホルムアルデヒド, ギ酸 などの気道刺激性物質に变化すると報告しており, 動物実験によりその健康影響を確認している。また Destaillats et $a l . .^{\text {? }}$ は, 家庭用品から放出されるテル ペン類とオゾンの反応において，ギ酸や酢酸などの 低級脂肪酸の生成を確認した。Reiss et al ${ }^{8}{ }^{8}$ は, 米 国ボストンの戸建住宅に押いて室内空気中アルデヒ ド類，ケトン類及びギ酸を含む低級脂肪酸の濃度之 オゾン濃度との関係を調べ, これら極性を有する揮 発性有機化合物間の濃度変化は互いに相関すること を明らかにした。関根ら”は東京都抢よび神奈川県 の新築集合住宅において室内空気中のホルムアルデ ヒド扔よびギ酸濃度を測定し, ギ酸の室内/室外濃 度比( $\mathrm{I} / \mathrm{O}$ 比), ギ酸/ホルムアルデヒド濃度比の季節 变化などからギ酸の発生源は室内に存在し, ホルム アルデヒドとオキシダントの反応により生成するこ とを示唆した。また小型椀型チャンバーを用いた実 験室実験により，フローリング用合板から放散した ホルムアルデヒドからオゾン拉よび二酸化窒素が関 与する気相ラジカル反応によりギ酸が生成すること を明らかにしだ゚。

一方, 空気中のギ酸は塩基性物質と反応するとギ 酸塩となり, 蒸気圧が低くなるためエアロゾル粒子 として存在する可能性がある。一般大気中では粒子 状ギ酸+の存在が確認されて抢り ${ }^{11)}$, その大気中濃 度レベルは米国に抢いて48-133ppt 報告されてい る ${ }^{12)}$ 。しかしながら, 室内空気中に抢ける測定例は なく, ガス状および粒子状ギ酸濃度分布は不明であ る。尚, ここで言う粒子状ギ酸とは, 空気中にェア ロゾル粒子として存在するギ酸の化学種であり，ギ 酸塩あるいはギ酸分子がエアロゾル粒子に吸着した 状態のものが想定される。

筆者らは室内空気中ギ酸濃度の測定に, 水酸化力 リウム水溶液を捕集液とするインピンジャ一捕集一 イオンクロマトグラフ法を用いてきた ${ }^{9-10)}$ 。しかし
本法では，ギ酸をガス状および粒子状に形態分離捕 集することができない。そこで本研究では, 前段に ガス状ギ酸を捕集するミニチュア拡散スクラバー (Miniature Diffusion Scrubber, MDS), 後段に粒子状 ギ酸を捕集するインピンジャ一を直列に接続した捕 集装置を作成し, 形態別分離捕集法を検討した。ま た本法を用いて実住宅に扮ける室内空気中ギ酸濃度 を実測したので報告する。

\section{2. 方法}

\section{1 捕集装置}

本研究で作成した形態別分離捕集装置をFig.1に 示す。本装置は, ミニチュア拡散スクラバー(ガス テック社製), ミゼットインピンジャー(柴田科学工 業社製)および吸引ポンプ(柴田科学工業社製積算流 量計付ミニポンプMP- $\left.\sum 30\right)$ から構成され, 前段で ガス状ギ酸, 後段で粒子状ギ酸を捕集するあのであ る。

ミニチュア拡散スクラバーは田中 ${ }^{13}$ によって開発 されたガス捕集装置であり, 全長 $13.5 \mathrm{~cm}$, 外管にポ リカーボネート管, 内管に多孔質ポリフルオロエチ レン（PPTFE）を用いた2重管構造になっている。内 管内に捕集液(水酸化力リウム水溶液, $1 \mathrm{ml}$ ) を充填 し, 外管と内管の間に空気を流通させると, 拡散し やすいガス成分のみが多孔質膜を通じて捕集液に移 動して吸収される。一方, 粒子状物質はそのままミ ニチュア拡散スクラバー外へ排出され, 下段のイン ピンジャ一内に入れた捕集液(水酸化カリウム水溶 液, $5 \mathrm{~mL}$ )で捕集される。

\section{2 捕集条件の検討}

ミニチュア拡散スクラバーによるガス状ギ酸の最 適捕集条件を検討した。水酸化カリウム(関東化学 社, 試薬特級)をイオン交換蒸留水に溶解して, 1, 5 および $7 \mathrm{mM}$ 水酸化カリウム水溶液を調製した。こ れを捕集液としてミニチュア拡散スクラバーに $1 \mathrm{ml}$ 加えた。同濃度の水溶液を加えたものを2本直列に 接続し,これを積算流量計付吸引ポンプに取り付け, ギ酸ガスを含む空気を流通した。捕集流量を $0.10 \mathrm{~L} /$ $\min お$ よび $0.16 \mathrm{~L} / \mathrm{min}$ に設定し, 捕集時間は 2 時間と した。ガス状ギ酸を含む空気は, ギ酸(関東化学社, 試薬特級)をイオン交換蒸留水で希釈し，これに純 空気を流量 $0.35 \mathrm{~L} / \mathrm{min}$ で吹き付けて常時発生させた。 生じたガスの一部をミニチュア拡散スクラバーに導 


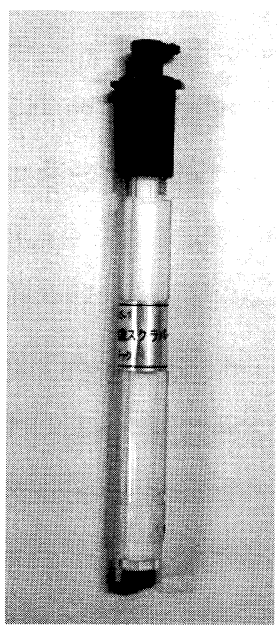

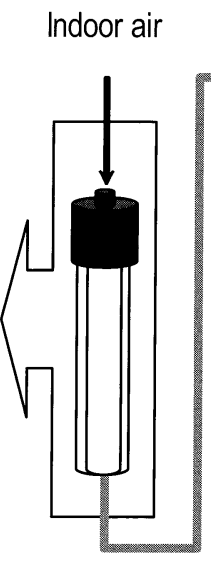

Miniature diffusion scrubber (MDS)

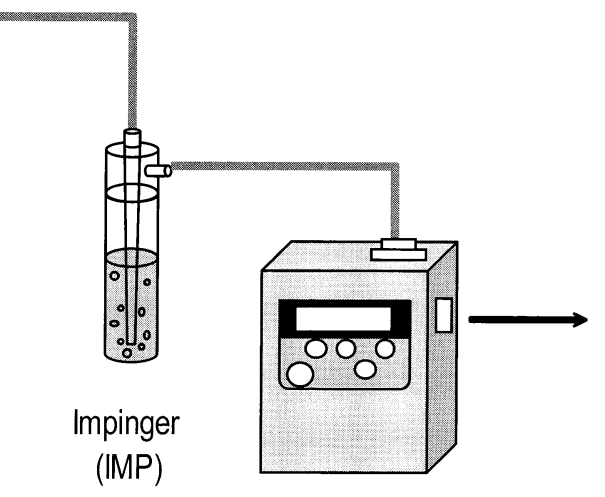

Air pump

Fig.1 Schematic view of the sampling method of gaseous formic acid and particulate formate in indoor air.

入して, 捕集効率を検討した。空気中ギ酸濃度は $0.22 \mathrm{mg} / \mathrm{m}^{3}$ であった。捕集後, 捕集液の揮発減量分 をイオン交換水で補って $1 \mathrm{ml} に$ 定容し，イオンクロ マトグラフィー装置によりギ酸イオンを定量した。 捕集効率 $R(\%)$ は (1)式により算出した。

$$
R(\%)=\frac{W_{1}}{W_{1}+W_{2}} \times 100
$$

ここで，Wl前段で捕集されたギ酸イオン量 $(\mu \mathrm{g})$, $W_{2}$ は後段で捕集されたギ酸イオン量 $(\mu \mathrm{g})$ である。

\section{3 再揮発の検討}

ミニチュア拡散スクラバーに捕集されたガス状ギ 酸の再揮発の有無を検討した。スクラバー内にギ酸 塩の水溶液を $1 \mathrm{ml}$ 加え, 後段には $1 \mathrm{mM}$ 水酸化カリウ ム水溶液 $5 \mathrm{ml}$ 含むインピンジャ一を接続し, 窒素 ガスを $0.10 \mathrm{~L} / \mathrm{min} て ゙ 2$ 時間通気した。ギ酸塩溶液には ギ酸カリウム(和光純薬工業, 試薬特級)を $1 \mu \mathrm{g} / \mathrm{mL}$ に調製したものを用いた。通気後, ミニチュア拡散 スクラバーおよびインピンジャ一の溶液の揮発減量 分をイオン交換水で補い, イオンクロマトグラフ装 置でギ酸イオンを定量した。

\section{4 ギ酸捕集量の比較}

インピンジャー法(従来法) と今回開発したミニチュ ア拡散スクラバーノインピンジャー法の捕集性能を 比較するため, 実験室内において室内空気を同時に 捕集し，ギ酸捕集量の比較を行なった。捕集液とし て, インピンジャーには $1 \mathrm{mM}$ 水酸化カリウム水溶
液 $5 \mathrm{ml}$ ：ミニチュア拡散スクラバーには $7 \mathrm{mM}$ 水酸化 カリウム水溶液 $1 \mathrm{ml}$ 用い, 捕集流量は $0.10 \mathrm{~L} / \mathrm{min}$, 捕集時間は 2 時間とした。捕集後, 捕集溶液の揮発 減量分をイオン交換水で補い，イオンクロマトグラ フィーによりギ酸イオンを定量した。

\section{5 実態調査}

神奈川県内の居住住宅2ヶ所(住宅A，B)において 室内空気中ギ酸濃度の実態調查を行った。住宅Aは 木造, 築年数 40 年の戸建住宅であり, 測定した部屋 の床面積は約 $18 \mathrm{~m}^{2}$ であった。測定は2006年8月10日 および9月13日に行った。住宅Bは鉄筋コンクリー 卜造, 築年数26年の集合住宅であり, 測定した部屋 の床面積は約 $18 \mathrm{~m}^{2}$ であった。測定は2005年11月 22 日に行った。測定日はいずれも晴天であった。空や 扉を閉め切ってから10時間後, 初期のギ酸濃度を測 定した。その後, 空や扉をすべて開放して60分間換 気を行い, 再び締め切った後に 3 時間ごとにギ酸濃 度を測定した。測定地点は部屋中央部高さ $1 \mathrm{~m}$ 地点 とし, サンプリング時は換気設備をオフにし自然換 気のみの条件とした。捕集にはミニチュア拡散スク ラバーノインピンジャー法を用い, 捕集時間は 3 時 間とした。

\section{6 分析方法}

ギ酸イオンは既報-100 に準じてイオンクロマトグ ラフ法により定量した。分析条件は以下の通りであ る。装置; Dionex社製ICS-90 Ion Chromatography 
System, 検出器; 電気伝導度検出器, 分離力ラム; Dionex社製IonPack AS-9HC Analytical $(4 \times 250 \mathrm{~mm})$, ガードカラム; Dionex社製IonPack AG4-4mm, サプ レッサー；AMMS III, 流量 ; $1.0 \mathrm{ml} / \mathrm{min}$, 注入量 ; $25 \mu 1$, 溶離液 ; $5 \mathrm{mM}$ 炭酸水素ナトリウム水溶液, 除去液； $15 \mathrm{mM}$ 硫酸。検量線用標準溶液は, $80^{\circ} \mathrm{C}$ て 乾燥したギ酸ナトリウム (関東化学株式会社, 試薬 特級) $0.0752 \mathrm{~g}$ を精秤し, イオン交換蒸留水 $50 \mathrm{ml}$ に溶 解し $\left(\mathrm{HCOO}^{-}: 1000 \mu \mathrm{g} / \mathrm{ml}\right)$ ，これをさらに希釈して 調製した。濃度はピーク面積法により求めた。

尚, 室内空気中の粒子状ギ酸の化学形態は現時点 では不明であるため, 本報ではガス状および粒子状 ともにギ酸分子 $(\mathrm{HCOOH})$ として濃度を算出した。

\section{3. 結果および考察}

\section{1 捕集条件の確立}

ミニチュア拡散スクラバーによりガス状物質を捕 集するには，管内の空気の流れが十分な層流，すな わちレイノルズ数 $(R e)$ が 2000 以下であることが必 要である ${ }^{14)}$ 。そこで, 通期流量 0.10 おる゙ $0.16 \mathrm{~L} / \mathrm{min}$ におけるレイノルズ数を求めた。2重管構造のレイ ノルズ数は(2)式で算出することができる。

$$
R e=\frac{2 r(1-K) V z \cdot \rho}{\mu}
$$

ここで $r$ : 外管の半径 $(\mathrm{m}), K$ : 管の閉鎖割合 (内 管外径/外管内径), $V_{z}$ : 平均速度 $(\mathrm{m} / \mathrm{s}), \rho$ : 空気 密度 $\left(\mathrm{kg} / \mathrm{m}^{3}\right), \quad \mu$ : 粘度 $(\mathrm{Pa} \cdot \mathrm{s})$ である。ミニチュア 拡散スクラバーの内管の外径は $6 \mathrm{~mm}$, 外管の内径 は $7 \mathrm{~mm}$, 大気密度は $20^{\circ} \mathrm{C}$ で $1.205\left(\mathrm{~kg} / \mathrm{m}^{3}\right)$, 大気粘度 は $1.8 \times 10^{-5}(\mathrm{~Pa} \cdot \mathrm{s})$ とすると, 通気流量 $0.10 \mathrm{~L} / \mathrm{min} の$ とき $R e=10.9$, 通気流量 $0.16 \mathrm{~L} / \mathrm{min}$ のき $R e=17.5$ と なり，層流条件を満たすことがわかる。したがって， 捕集液がギ酸を十分に吸収できれば，高い捕集効率 が期待される。

Fig.2にミニチュア拡散スクラバーのガス状ギ酸 捕集効率に及ぼす水酸化力リウム水溶液濃度の影響 を示す。各条件での測定はそれぞれ4回行なった。 捕集流量 $0.16 \mathrm{~L} / \mathrm{min}$ では捕集溶液濃度の増加に伴っ て捕集効率が増加し，溶液濃度 $7 \mathrm{mM}$ のさき最大 $85 \%$

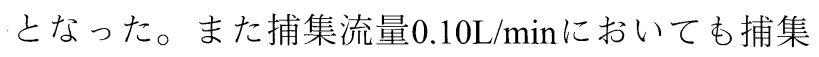
溶液濃度の増加に伴って捕集効率が増加し, 最大捕 集効率は溶液濃度 $7 \mathrm{mM}$ のき $94 \%$ となった。水酸化 カリウム水溶液の濃度が高いほど捕集効率は向上す るが，7mM以上にするとイオンクロマトグラフ測

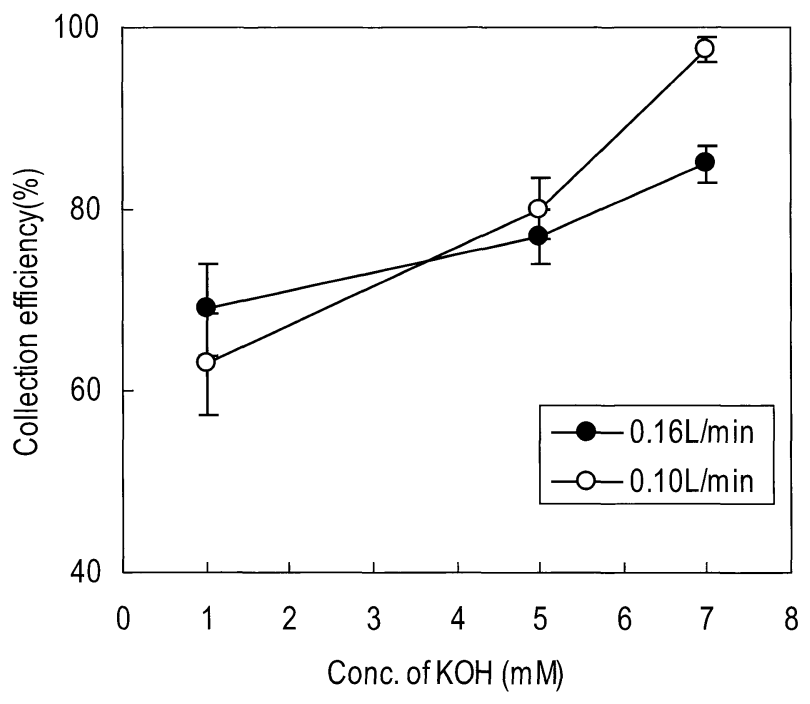

Fig.2 Effect of aqueous concentration of potassium hydroxide on the collection efficiency of gaseous formic acid in air by the miniature diffusion scrubber at a flow rate of 0.10 and $0.16 \mathrm{~L} / \mathrm{min}$ (temp.: $17-20^{\circ} \mathrm{C}$, R.H.:23-40 \%).

定においてピークに異常が生じるため, これ以上捕 集溶液濃度を高くすることができない。よって，ガ ス状ギ酸の捕集条件は，捕集流量：0.10L/min，捕 集溶液： $7 \mathrm{mM}$ 水酸化カリウム溶液 $1 \mathrm{ml}$ と決定した。 また，この捕集条件においてギ酸濃度を変化させ， ガス状ギ酸の捕集効率を調べた結果，ギ酸濃度 $0.049 \mathrm{mg} / \mathrm{m}^{3}$ の時は $96 \%, \quad 0.031 \mathrm{mg} / \mathrm{m}^{3}$ の時は $99 \%$ とな り, $0.0042 \mathrm{mg} / \mathrm{m}^{3}$ の時は $W_{2}$ が検出下限以下となった。

\section{2 再揮発の検討}

ミニチュア拡散スクラバーからのギ酸の再揮発の 有無についての検討を行った。ギ酸分子 $(\mathrm{HCOOH})$ は水中では電離して, ギ酸イオン $\left(\mathrm{HCOO}^{-}\right)$と電離 平衡に達する。

$$
\mathrm{HCOOH}+\mathrm{H}_{2} \mathrm{O} \rightleftarrows \mathrm{HCOO}^{-}+\mathrm{H}_{3} \mathrm{O}^{+}
$$

水中に水酸化力リウムのような塩基性の電解質が 含まれる場合, 平衡は右に移動してギ酸イオンがよ り多く生成するため, ギ酸分子 $(\mathrm{HCOOH})$ の気相へ の再揮発は生じにくいと考えられる。Table 1にミ ニチュア拡散スクラバーに添加したギ酸カリウム水 溶液からのギ酸揮発量の検討結果を示す $(n=5)$ 。 クラバー内のギ酸カリウム量は, 窒素ガス通気前と 通気後で有意な差は見られず，下段のインピンジャー からはギ酸イオンを検出することはできなかった。 このことから，ミニチュア拡散スクラバーで捕捉さ れたガス状ギ酸の再揮発は生じないと考えられる。 
Table1 Retained potassium formate in the miniature diffusion scrubber and amount of formic acid detected in the second stage impinger, after passing nitrogen gas through the MDS/IMP sampling apparatus for 2hours (The sampling apparatus was operated in the experimental room under $13^{\circ} \mathrm{C}$ and $36 \%$ of relative humidity). ND: not detected.

\begin{tabular}{cccc}
\hline \hline & \multicolumn{2}{c}{$\mathrm{HCOOK}(\mu \mathrm{g})$} & \multirow{\mathrm{HCOOH}}{*}{$(\mu \mathrm{g})$} \\
in & added & retained & impinger \\
\hline 1 & 0.99 & 0.98 & $\mathrm{ND}$ \\
2 & 0.99 & 0.97 & $\mathrm{ND}$ \\
3 & 1.1 & 1.1 & $\mathrm{ND}$ \\
4 & 1.1 & 1.1 & $\mathrm{ND}$ \\
5 & 1.1 & 1.1 & $\mathrm{ND}$ \\
\hline
\end{tabular}

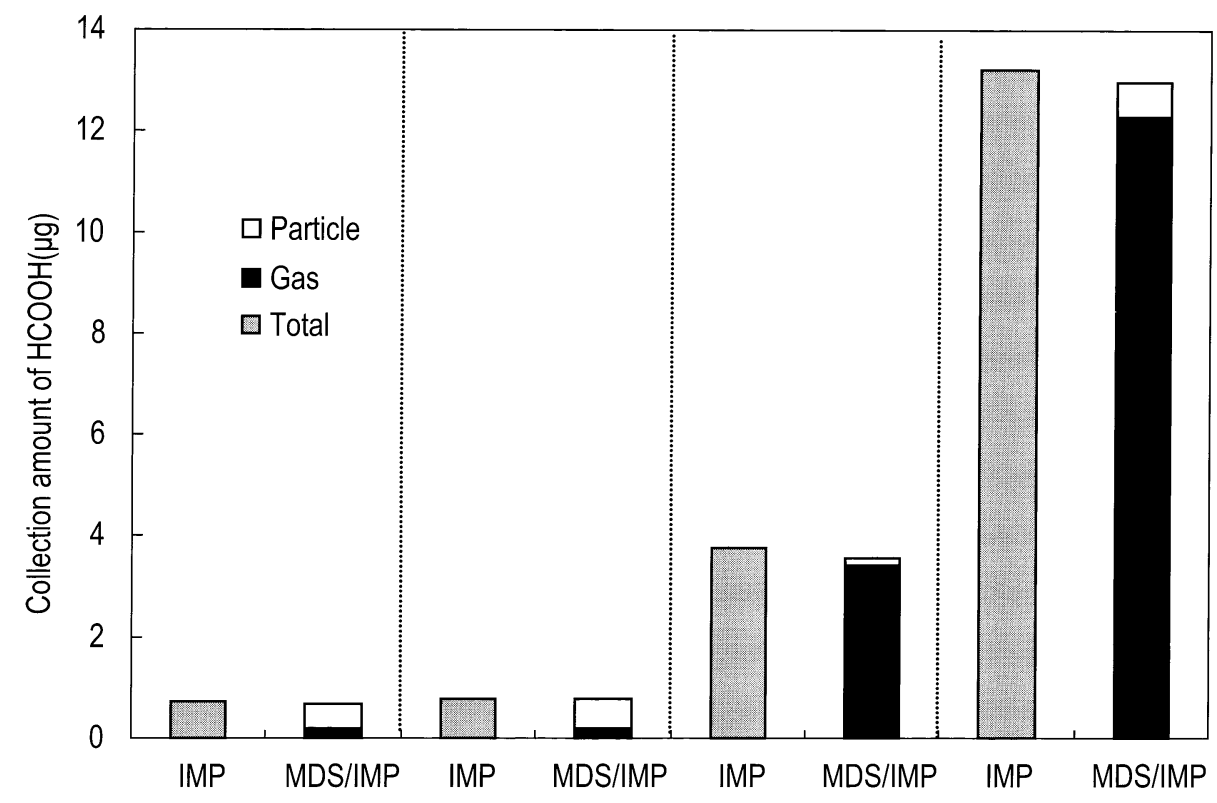

Fig.3 Comparison of total collection amount of formate species as $\mathrm{HCOOH}$ collected by a previous impinger method (IMP) and this method (MDS/IMP) at varying concentration levels of formic acid in indoor air (temp.: $21^{\circ} \mathrm{C}$, R.H.:33 \%).

\section{3 捕集量の比較}

一方，ミニチュア拡散スクラバーを粒子状物質が 通過する際に，ごく一部が壁面に沈着して通過して こない可能性がある。粒子状物質の理論透過率は, 粒径分布に応じてGormley-Kennedyの式によって推 測することができる ${ }^{14)}$ 。しかしながら粒子状ギ酸が 存在するとしても，その粒径分布は明らかではない。 そこでここでは従来法(インピンジャ一法) と本法と の総ギ酸捕集量の比較により検討した。Fig.3に結 果を示す。実験室内において濃度レベルを变えて同 時測定を行い，捕集量を比較した結果，総ギ酸捕集 量の本法/従来法比は $0.94 \sim 0.98$ となり，良い一致を 示した。このことから，ミニチュア拡散スクラバー
内に粒子状ギ酸は浸透しないことがわかった。

\section{4 ブランクレベル, 検出下限, 定量下限}

本法による測定において，ミニチュア拡散スクラ バーおよびインピンジャーから有意なギ酸のブラン クレベルが検出された。ミニチュア拡散スクラバー のブランクレベルは, 蒸留水のみで洗浄して用いた 場合 $0.084 \pm 0.035 \mu \mathrm{g}(n=20)$ であり, 実環境では十 分な感度が得られない。そこで使用前の洗浄方法を 見直し，イオン交換水1Lを入れたビーカーにミニ チュア拡散スクラバーを入れ，このビーカーを $30^{\circ} \mathrm{C}$ に設定した超音波洗浄機に移して30分間洗浄し，こ れを2回行なった後，スクラバーをイオン交換蒸留 

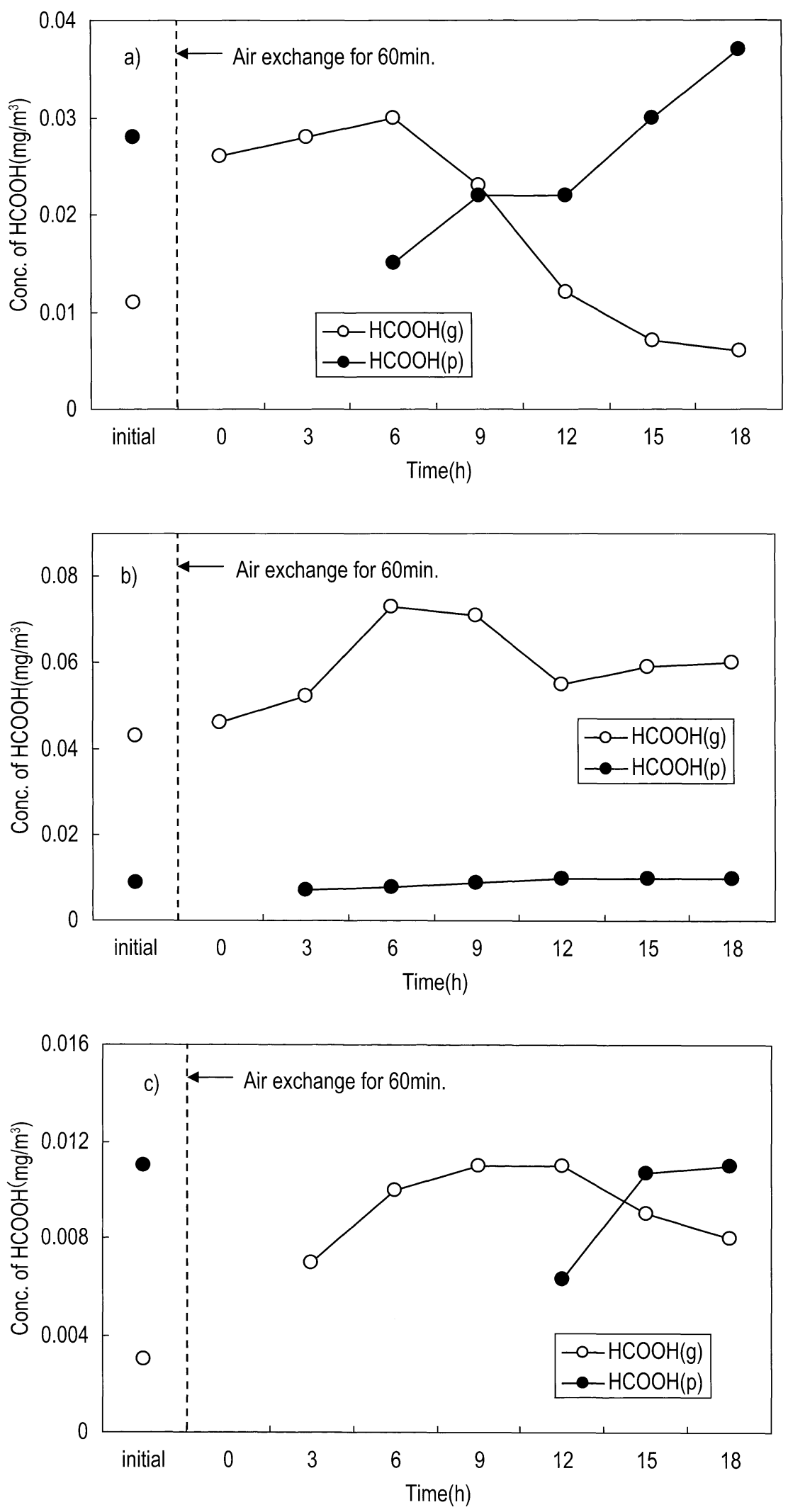

Fig.4 Variations of indoor air concentrations of gaseous formic acid $(\mathrm{HCOOH}(\mathrm{g}))$ and particulate formate $(\mathrm{HCOOH}(\mathrm{p}))$ in indoor air of occupied houses, before and after air exchange for 60 minutes (a) House A, 13 September, 2006, b) House A, 10 August,2006, c) House B, 22 November, 2005). 
水で十分にすすいで乾燥させた。その結果, この洗 浄方法に基づいて用いたミニチュア拡散スクラバー のブランクレベルは $0.026 \pm 0.0078 \mu \mathrm{g}(n=20)$ に低減 した。一方, インピンジャーのブランクレベルは $0.11 \pm 0.026 \mu \mathrm{g}(n=7)$ であった。検出下限を $3 \sigma$, 定量下限を $10 \sigma$ と定義すると, 本法による空気中ギ 酸濃度の検出下限値は, 捕集流量 $0.10 \mathrm{~L} / \mathrm{min}$, 捕集 時間3時間において, 粒子状ギ酸: $0.0044 \mathrm{mg} / \mathrm{m}^{3}$, ガ ス状ギ酸： $0.0013 \mathrm{mg} / \mathrm{m}^{3}$ となった。これらの検討結 果を踏まえて, 室内空気中のギ酸濃度の実態調査を 行った。

\section{5 実態調查}

居住住宅に打ける室内空気中ギ酸濃度の経時变化 をFig.4a)〜c) に示す。Fig.4a) は住宅Aにおいて 2006年9月に測定した結果である。同住宅において 外気中のギ酸濃度を測定したところ, ガス状ギ酸は $0.0040 \mathrm{mg} / \mathrm{m}^{3}$ ，粒子状ギ酸は検出下限以下であった。 一方, 前日から10時間締め切った状態で測定した初 期の室内空気中濃度は, ガス状ギ酸 $0.011 \mathrm{mg} / \mathrm{m}^{3}$, 粒 子状ギ酸 $0.028 \mathrm{mg} / \mathrm{m}^{3}$ となり, 粒子状ギ酸濃度を定量 することができた。またこれらギ酸濃度は，外気よ りも室内空気の方が高かったことから, 室内環境中 にギ酸の発生機構が考えられ, 先に筆者らが示唆し たように，外気から導入されたオキシダント(オゾ ン, 二酸化窒素など) と室内発生源から放散される 揮発性有機化合物の反応によって生成した可能性が 考えられる。一方，この初期測定では粒子状ギ酸の 方がガス状ギ酸濃度よりも高い值を示したが，60分 間換気した後，再び締め切った状態で3時間ごとに 室内空気中ギ酸濃度を測定した結果, はじめはガス 状ギ酸のみが検出され，その濃度レベルは初期測定 よりも高く，9時間後から徐々に減衰する傾向が見 られた。それに対して粒子状ギ酸は，換気直後には 検出されなかったが，ガス状ギ酸の減衰に伴って堌 加し，やがて粒子状ギ酸の方がガス状ギ酸よりも高 濃度となった。同様の傾向は，住宅Bにおいても観 測されたFig.4c)。尚, 住宅Bの外気中のギ酸濃度は, ガス状，粒子状とあに検出下限以下であった。この ことは, 室内空気中のギ酸は, はじめはガス状物質 として生成し, 徐々に粒子化していくことを意味し ている。

ギ酸の粒子化機構として, 空気中のガス状塩基性 物質 (アンモニアなど) との反応に伴うギ酸塩 (ギ酸
アンモニウムなど)の生成，および空気中エアロゾ ル粒子への吸着などが考えられる。しかしながら， 住宅Aで別の日に同様の測定を行ったところ, Fig.4b）に示すようにガス状ギ酸は $0.046 \mathrm{mg} / \mathrm{m}^{3}$ $\sim 0.071 \mathrm{mg} / \mathrm{m}^{3}$ の範囲で変動したが, 粒子状ギ酸はほ ぼ $0.01 \mathrm{mg} / \mathrm{m}^{3}$ で变動は見られなかった。尚, 外気中 のガス状ギ酸は $0.0047 \mathrm{mg} / \mathrm{m}^{3}$, 粒子状ギ酸は検出下 限以下であった。このことから，ガス状ギ酸の粒子 化機構に関しては不明な点が多く, 環境条件や共存 物質の影響を考慮して検討する必要がある。

\section{4. 結論}

本研究によって開発したミニチュア拡散スクラバー ノインピンジャー捕集 -イオンクロマトグラフ法に より, 室内空気中のギ酸濃度をガス状および粒子状 に分けて測定することが可能になった。本法を用い て実住宅において実態調査を行ったところ, 室内空 気中のギ酸は, はじめはガス状物質として生成し, 徐々に粒子化していくことがわかった。ギ酸の粒子 化機構として, 空気中の塩基性物質との反応に伴う ギ酸塩の生成, および空気中エアロゾル粒子への吸 着などが考えられるが，同一住宅でも測定日によっ て粒子化が起こらない場合も観測され，粒子化のメ カニズムは不明な点が多い。今後は，ガス状ギ酸の 粒子化機構を明らかにし, 化学反応を伴う室内内空 気中ギ酸の挙動の解明に寄与したい。

\section{引用文献}

1）石橋美生, 三木猛生, 和田耕治, 遠乗秀樹, 角田 正史, 相沢好治, 坂部貢, 宮田幹夫, 石川哲：シッ ク八ウス症候群の臨床分類, 臨床環境医学, 14(1), 46-52(2005).

2) 安藤正典: 室内空気污染之化学物質, pp584587, 化学工業日報社, 東京(2002).

3）三好基晴, 北之園明久, 白川太郎, J. M. Hopkins, 宮田幹夫 : 抗菌コート住宅がアレル ギーを増やしている, 第3回室内環境研究大会 研究発表会講演抄録, 46-47(1997).

4) P. Wolkoff, P. A. Clausen, C. K. Wilkins, K. S. Hougaard, G. D. Nielsen: Formation of strong airway irritants in a model mixture of $(+)-\alpha$ pinene/ozone, Atmos. Environ.,33,693-698(1999).

5) P. A. Clausen, C. K. Wilkins, P. Wolkoff, G. D. Nielsen:Chemical and biological evaluation of a 
reaction mixture of $\mathrm{R}-(+)$-limonene/ozone: formation of strong airway irritants. Environ. Int., 26(7-8), 511-22 (2001).

6) C. K. Wilkins, P. A. Clausen, P. Wolkoff, S. T. Larsen, M. Hammer, K. Larsen, V. Hansen, G. D. Nielsen: Formation of strong airway irritants in mixtures of isoprene/ozone and isoprene/ozone/ nitrogen dioxide, Environ. Health Perspect., 109(9),937-41(2001).

7) H. Destaillats, M.M. Lunden, B.C. Singer, A.T. Hodgson, W. W. Nazaroff, B.K. Coleman, C.J. Weschler,: Indoor Secondary Pollutants from Household Product Emissions in the Presence of Ozone: A Bench-Scale Chamber Study, Environ. Sci. Technol., 40 (14), 4421-4428 (2006).

8) R. Reiss, P. B. Ryan, S. J. Tibbetts, P. Koutrakis: Measurement of organic acids, aldehydes, and ketones in residential environments and their relation to ozone, J. Air Waste Manag. Assoc., 45(10),811-22 (1995).

9）関根嘉香, 西村厚司, 末永義明, 小峯裕己：室
内空気中ホルムアルデヒドおよびギ酸濃度の実 態調査と低減化実験, 日本建築学会計画系論文 集，548，51-55(2001).

10）関根嘉香, 臼杵英俊, 宮城圭輔, 小座野貴弘： 室内空気中ギ酸濃度に及ぼす外気由来の才キシ ダントの影響, 環境化学(2007)印刷中

11) P. Khare, N. Kumar, K. M. Kumari: Atmospheric formic and acetic acids: an overview, Reviews of Geophysics, 37, 227-248(1999).

12) H.A. Khwaja: Atmospheric concentrations of carboxylic acids and related compounds at a semiurban site, Atmos. Environ., 29,127-139 (1995) .

13) S. Tanaka: Development of measurement method of indoor air pollutant gases by using miniature diffusion scrubber and LED photometer, Proc. of $8^{\text {th }}$ Intern. Conf. on Atmos. Sci. and Appl. to Air Quality (ASAAQ),273(2003).

14）田中茂：拡散スクラバー法を用いた大気污染ガ スの計測技術，大気環境学会誌，41，A14A26 (2006). 